\title{
斯大林論語言翼的著作給研究少 數民族語言的指示
}

\author{
羅 季 光
}

斯大柇同志有閶民族間題的萻作，使我們對 少數民族的語言問題存了一偑正確的香法; 他的 論語言學的著作，使少数民族語言工作者得到了 更具體的指示。

新民主主義的革命，使少數民社衙破了反動 統治的叙鍊, 獾得了自由, 他們被反動統治階敋企

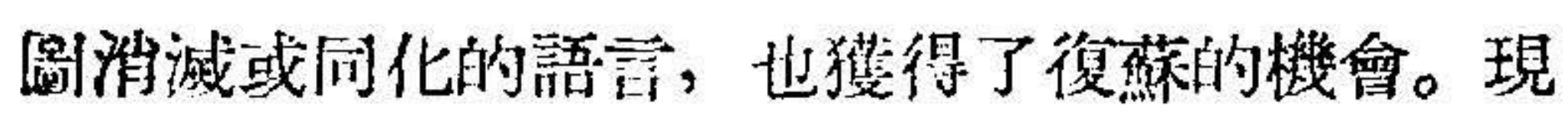
在，我們少數民族語言工作者的任務便是幫助少 數民族墢展他們的部蓄。

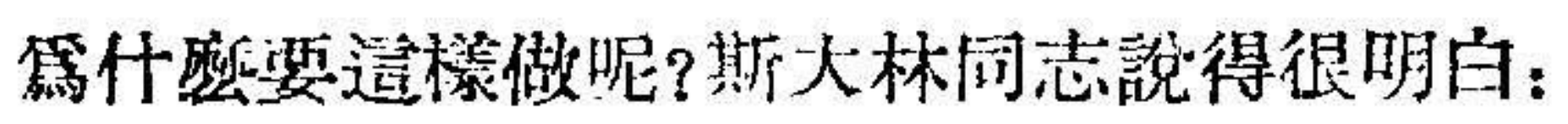

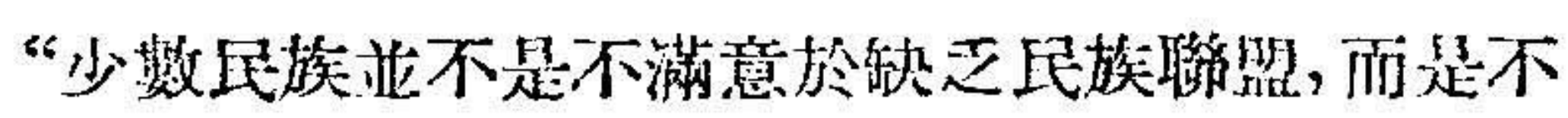
滿意於缺乏本族語言使片權。掌他們一旦㩁侍本 族語言使肞權洔，這種不滿就會自然消尔下去的 了。”(“馮克思主義與民族閏题”) 又說: “如果注意 到我國文盲率仍然很大，我國許多民族的文目党 佔人口百分之八十到九十，那末怎榢能做到這照 (案指损起蘇嵫的文化革命一一筹者)呢? 䈍此就 必須在全國起立使用本民族留言的學校網，供給 精通本民族語言的敎的人材。……焦此就必須展 開創辦使用本民族語言的報刊、戲院、電影院以及

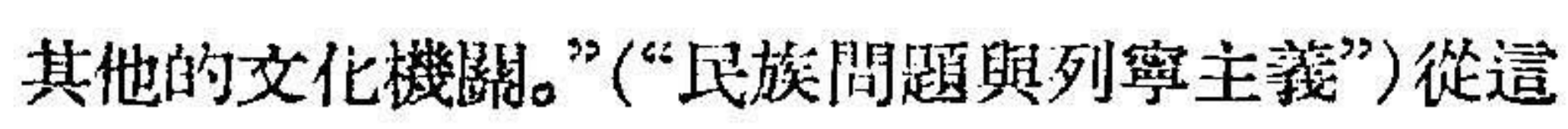
裹找們不但明確認識了研究少數民族語言的目的 和任務, 並且看出了我們過去從事這種工作的人 的錯諨的研究態度。我們過去喜歡㸴究現象特别 的語言，那怕說這種話的只有幾面人，我們便把企 部精神用進去; 對那些語言現像“普通”一點的, 那 怕是侍幾萬幾十萬的人在說, 我們可以整時擱谓 不理。我們的研究, 只着重於“新奇的滕現”, 忽略 語言一般性的規律。这種研究只是資本主義式的 装點門面, 只是些不顧實際的學院计的研究。雖然 也有成績, 但很少是我們今天國家人民所需要的。
今日我們少数民族語言工作者只有一個目的和任 務; 繁助少數民族發展他們的語言，以便提高他們 的文化。如果我們心裹還横着一㨐如何使少數民

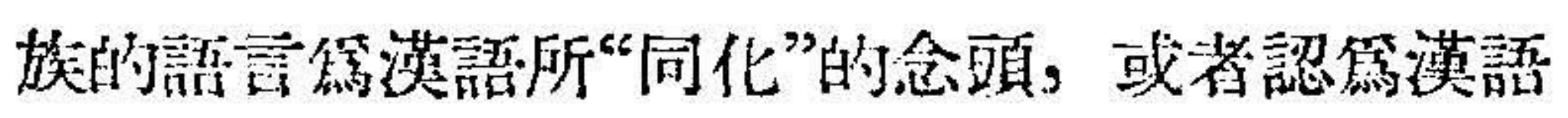

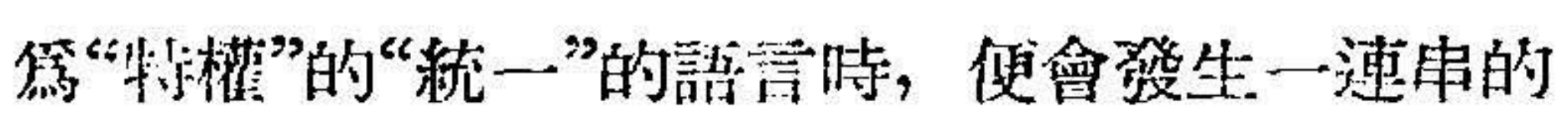

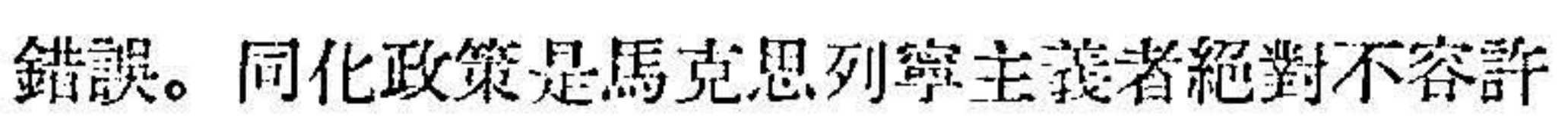
探用的。斯火林同志說: “暦史婊明, 語言有巨大的 穞固性和抗拒强迫同化的極大的抵抗性。…... 耳其人企圖同化巴爾幹各族人民，㲘在幾百年中

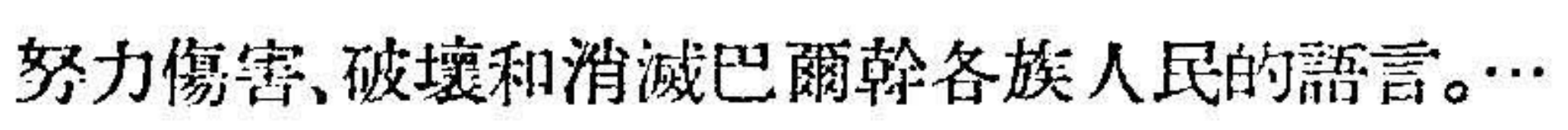
…可是巴爾幹各族人民的部需還是堅持下來和活 下來了。”(“論馬克思主军在語言學中的問題”。以 下引活皆阔。)這是少數民族語言工作者㗹當注意 的。

首先是少數民族的“民族語”間題，少數民族

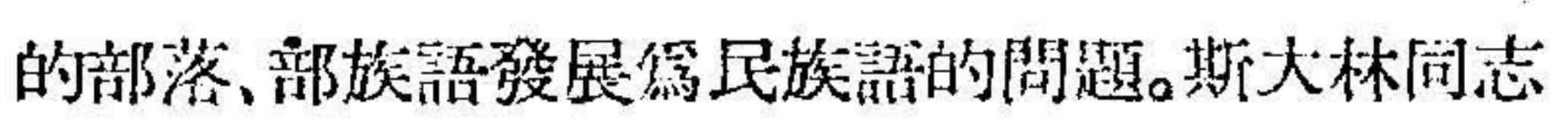
在“論馬克思主義在語言學中的問題”中說: “至於 語言的繼續發展, 從氏族語言到部落語言, 從部落 語言到部族語言，從部族語言到民族語言，在所有 這一切階段上，作篇人們在社會中交際的工具的 語言是全社會統一的、共同的, 是對社會所有組成 員同樣服務的，而不管他們的社會地位怎樣。”這 告培我們部族語“可能”發展第民族語。同洔斯大 林同志用了很多篇幅反覆說明民族語的必要和必 然存在。他引證馬克思承認“必須有統一的民族語 言作第最高形式”。他告訴我們: 地方方言在民族 形成的過程中, 可以成篇民族語的基礎, 並能發展 成篇獨立的民族語。“部落和部族統一的和共同的 語言是佔着統治地位, 並使這些方言、士語服從自 己。”此外的方言士語, 參加這種“形成”的工作。它 們朝造一種方言的方向向前發展, 它們在自己的 


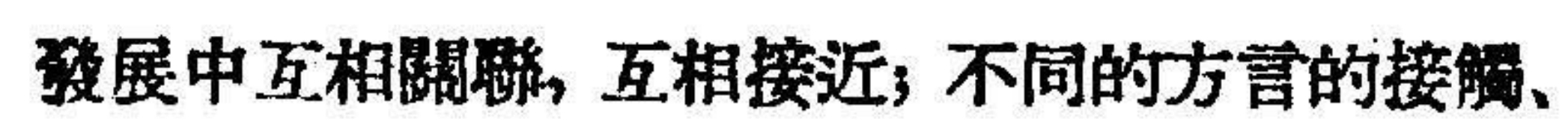
集中和最後萿合，部族語便形成第民族語。方言的 集中並不會創透一種和水來的部族語言相反的超 乎方言之上的特殊民族語, “而是透向於本部族語 所有方言的集中或梳一，向於在一種可以作篇 民族語基磷的方穹上接近和䀅和。一句話, 便是民 族語使這些方言士語服從自己。這健是民潪語形 成的過程。我國少數民族的語言可能而且必要由 部族語言形成䉆他們的民族語。少數民族語言仍 停帮在部族語言的狀態中, 方言過分的分敁複雜, 這對於提高文化是一做很大的障礙。至於以哪一 種方言䉆民族铻的基堡呢? 斯火林同志引了馬克 思的話解决了造一問題: “方言照慣語集中第統一 的民族語言是由經济和政治的集中來决定的。”以

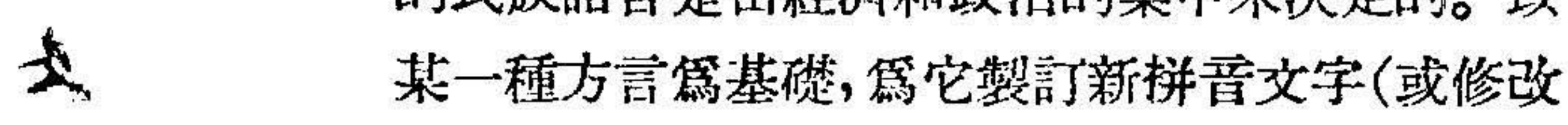

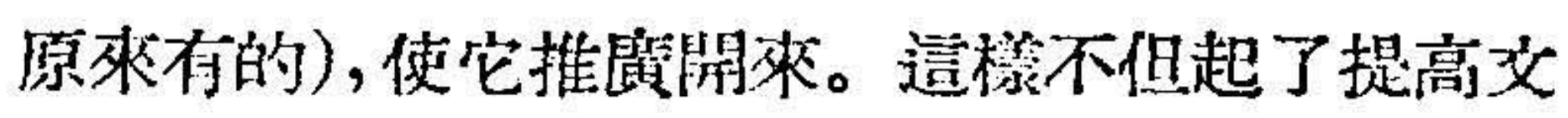
化的作用, 而且促進了民族铻的加速形成。我國西

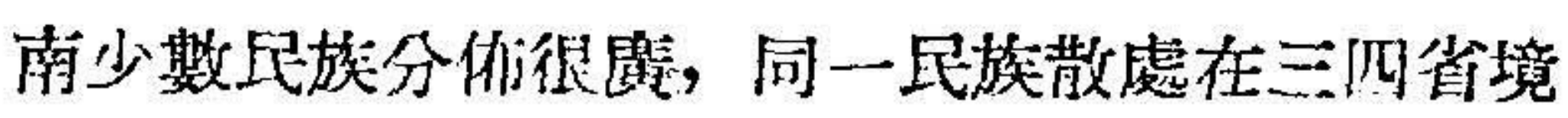
內的很多。我佃媱他們製訶拼音文字時, 由於區域 及方言差别過大的原故，不必硬使它轅定第一種。 就是說, 這一王族的民族語的形成, 可分雹幾個區 域幾倜步驟進行。待後, 各單位區域語言互相笡合 吸收, 逐漸上升成篇更高一粉的形式。而且這一省 的一種少數民族語言不必一定要跟别一省相距很 遠的同族語言起融合作用（事賽上有很多困難), 而可跟同一少內相隣近的别語系相近的一少數民

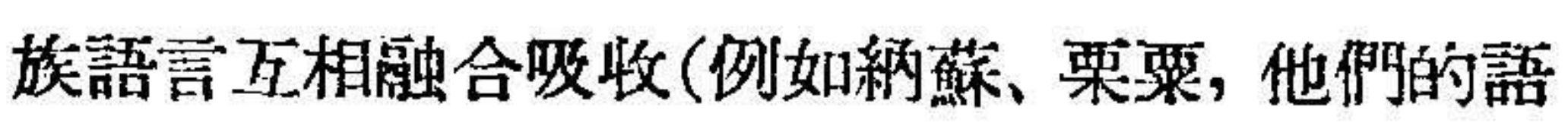

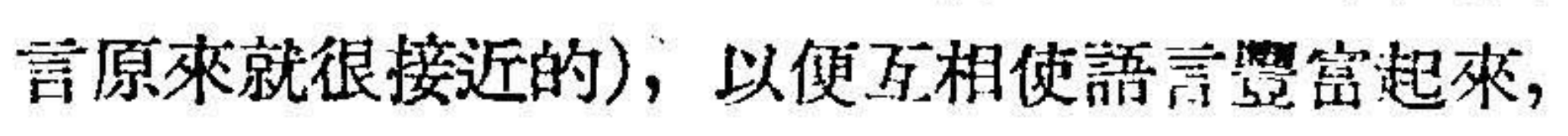
發展起來。因此，篇少數民族語言整訂或修改文字 時, 要使文字有足够的彈性, 以俅融合吸收其他的

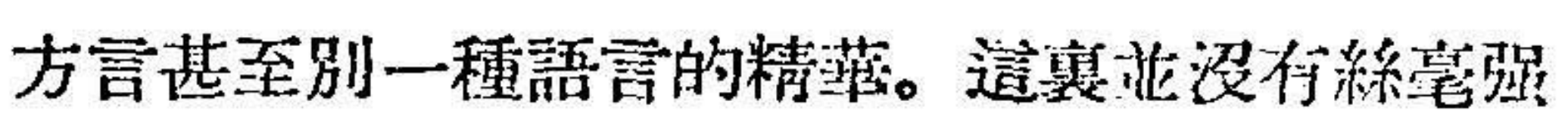
迫“同化”的企圖, 或故意作人篇的“語言交配”，運 是他們社會政治、經济、文化長期合作後的必然的 “語言交融”，而且這種現像在很久以前他們号已 互相發生了的。

其次, 便是少數民族學想漢語漢文的問題。我 們要求少數民族的交化很快地接近新民主主義一 般的文化水平。因此我們要使少數民族跟其他的 中華人民共和國人民學皙一種共同的語言。學替 共同語言的目的, 只是在使他們的文化發鼠得更 快更好。“語言是工具、武器, 人們利用它來百.相交 際, 交流思想, 達到互相膫解。” “可見汥有全妙會

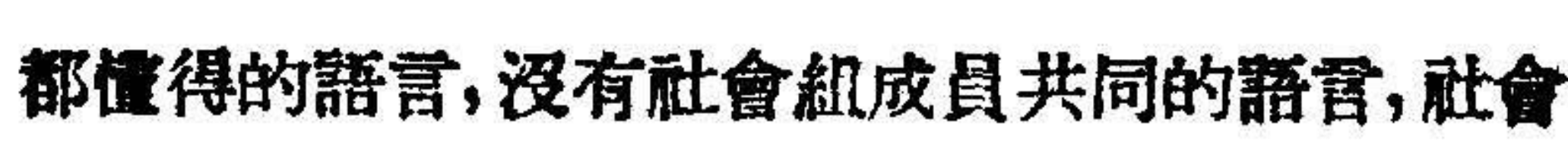

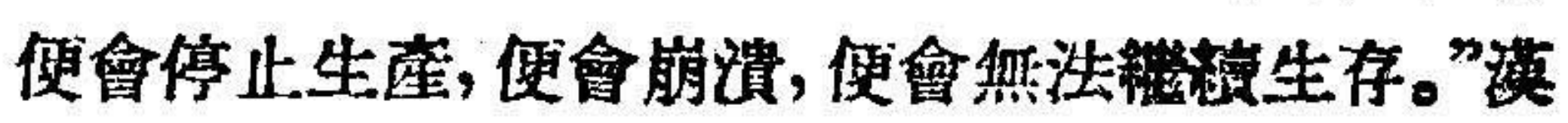
語在經济和文化發展的坴部進程中，"已上升到了 至中苝人民共和國的共同語的地位。因之，學替漢

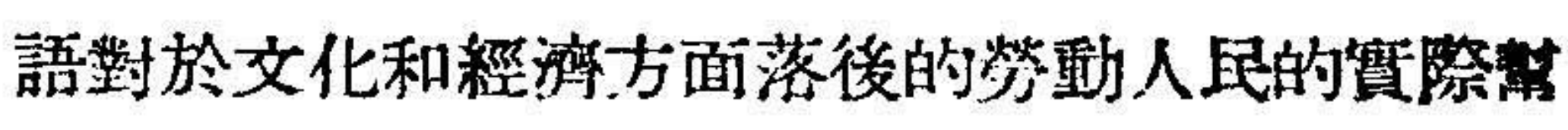
助准極重要的意義。造並沒有大漢族主義的絲毫

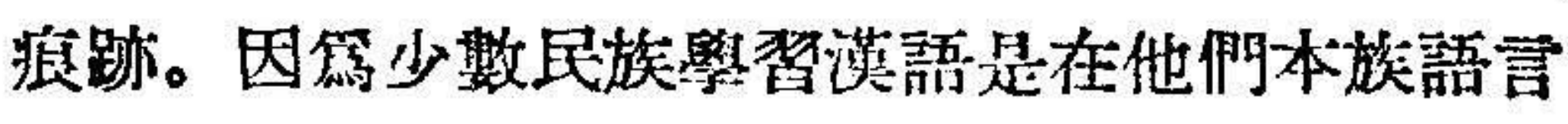
發展的基礎上實現的，而不是在本民族語言的消 隇或被聧迫的基堡上實現的。少數民族語言工作 者不容忽視這一項工作。我們隹該有一批熟槷本 民族語文同時文精通漢浯漢文的幹部，繁助少數 民族學替漢語漢文。如果少數民族語言工作者只 研究或學皙少数民族語言, 而認篇想助他們學替 漢語漢交是別的幹部的事, 自己“不感興趣”，甚至

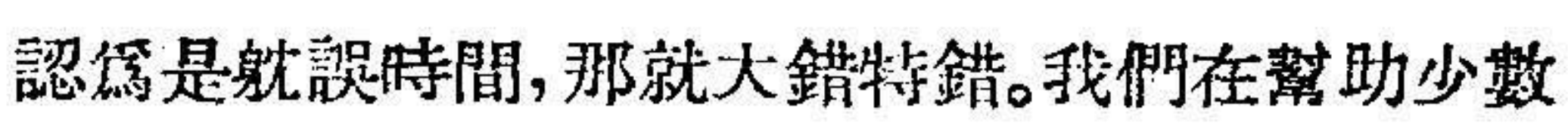
民族學相漢語漢文時，應該特别注意那些漢語漢 交所具存而某民族語言所缺少的束酒，並作“雨種 語言彼此間在文法上的必要對照。”(“蘇聯教育界 對斯大林語言學著作與改進語言教學討論會的總 結”）我們逶樣做了，少數民族語言和各卫族間共 同語言的融合過程是不是而延續得更長呢? 這栚 是不是會使中國境內的語言更綵繁䙓雑了呢? 斯 大林同志早已告訴了我們: 各湖民族語言跟各民 族間共同的語言有一個共存階段, 而且造一階段 第時還不會很短。我們認篇造储体民族語言跟各 民族間共同語言的共存階段是必不可少的, 是提 高少數民族文化最有效而且是倠一的辦法, 我們

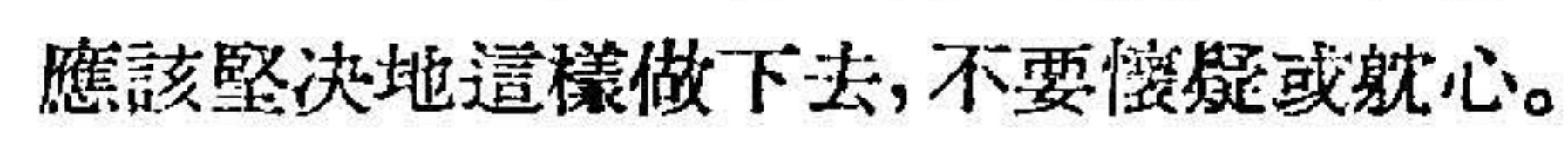

我們很容易碰到另外一僻問題：篇少数民族

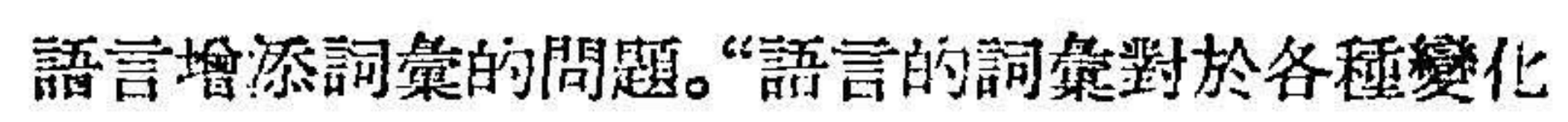

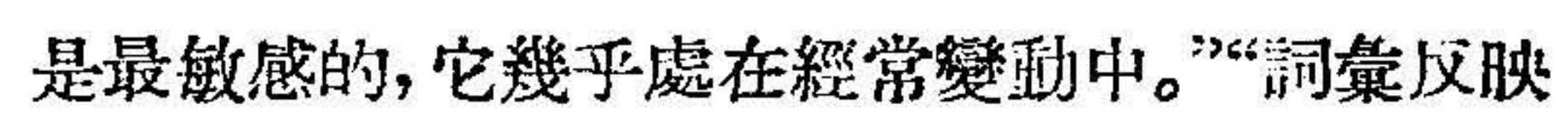

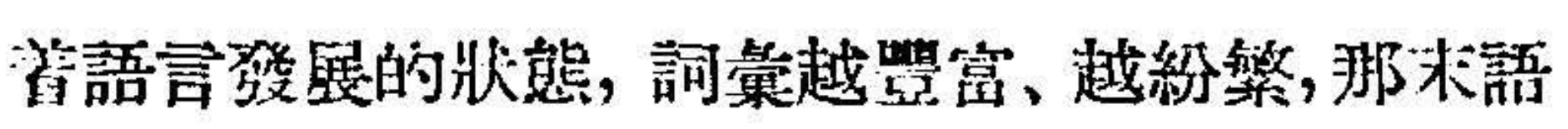
言也就越豐富、越發展。”在解放挠進入新民主主

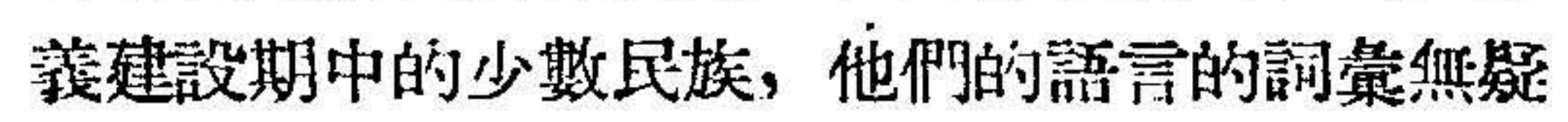

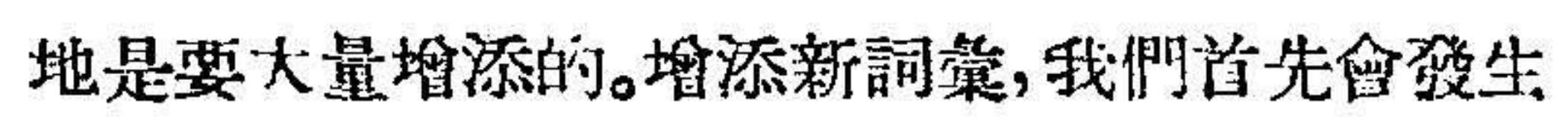
用什焽形圷或構造方式的問题。斯大林同志對造, 倜問題是存指示的。他說: “語言的詞策的變化不 是像上居建築一樣。它的變化不是用廢除舊的、建 設新的那程方法爽賽現的, 而是用新詞去充䁈現 行的詞輍的方法來實現的, 這些新詞是由1於垌會 制度改彎，由於生產、文化、科學等管㹩展的結果

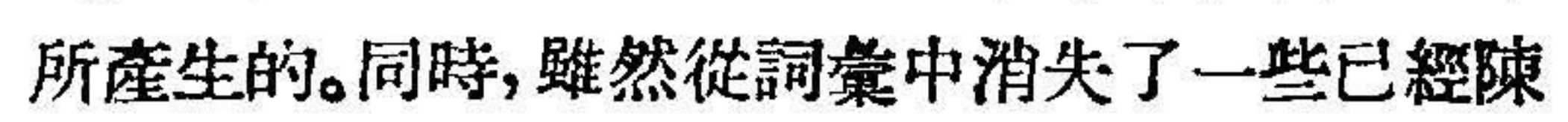




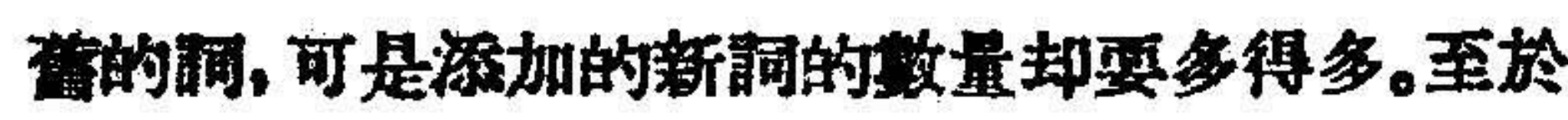

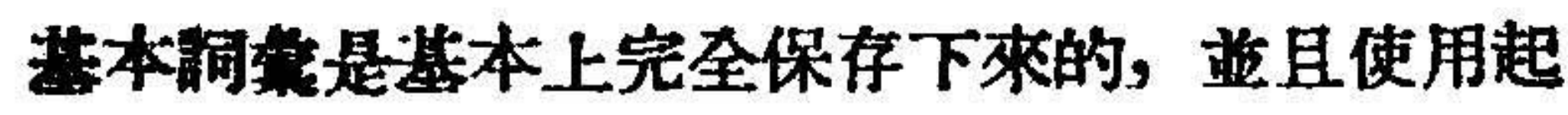
来作篇語言的詞黨的基礎。”他指示我們聕添新詞

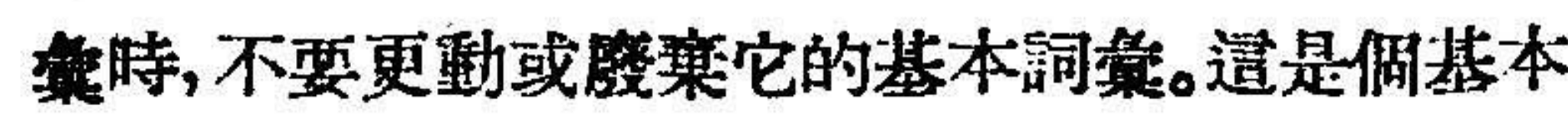
原则。我們所要㲘添的只是 “由於社會制度改變, 由於生產、文化、科學等等發展的結果所產生”的 詞致。換言之，我們只借入本民族原來所汥有的詞

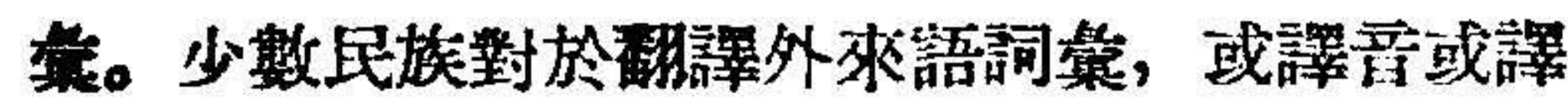
義, 早就有了他們的辦法。這程借譯外來語詞兴的 就法, 不論有幾種, 美不多都已成第他們铻言內部 規律的一部分了。我們現在篇他們㒄添新菏量也 應該先尋州他們原有的規律, 然後有選摆地按照 一定的結㮖形式來翻譯新詞策。選摆健康的霞大

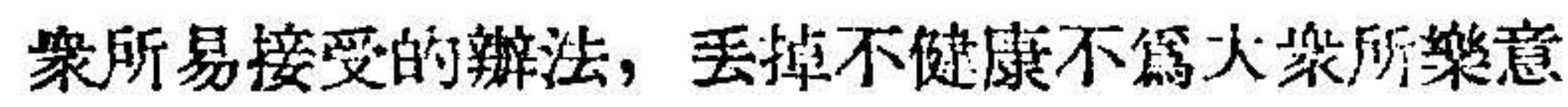
接受的方式。攃初步調查的結果, 各少數民族大部 分敩用譯要的方式。那末，我們大量探用造種方式 就是了, 用不着懹疑。這是他們詞策結構規律所肯 定了的。有了翼賉基礎，而不是自作聰明，由比而 下，用强迫手段硬製定出來的詞，沒有不被大㖣所 鹳迎的。有人顧虑用造種青譯法製出来的新詞，不

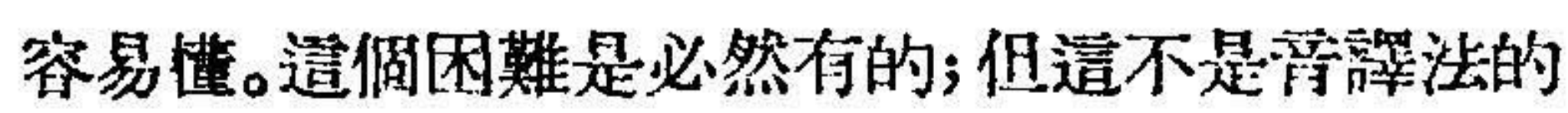
缺點,'而是任何一倜新䛔對勞動人民必然發生的

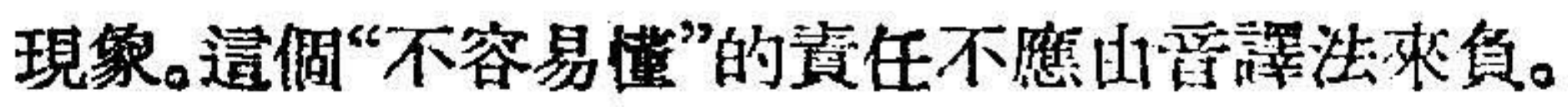
䈔求解决困難的辦法，應該從别的方面如教學方

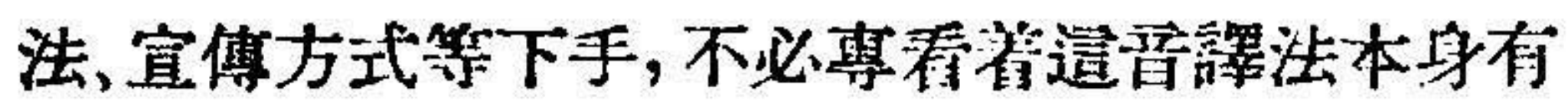
毛疾。有誰能保登漢語“土改”這储詞對一些等動 人民解說時能一下子就使他們领悟了呢? 在今天 又有哪一倜等動人民還不懂或不會䏳“土改”這一

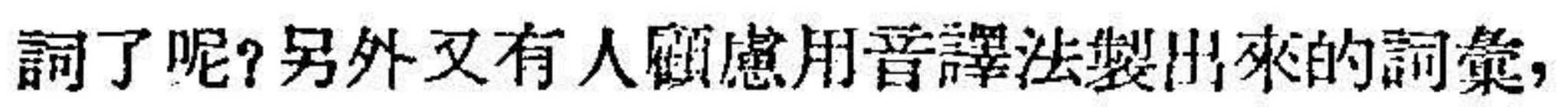
有時會破壞本民族語言原有的語词結棤形式，椇 害了這一程語言的完整性。遵也不成問題。吾譯語 詞容或有和原來語詞結構不相同的地方, 但是這 種“例外”，他們是已哯第他們語言內部的規律之 一了, “破壞”原來語訶形式的音譯法他們早已“安 之渃素”了。我們賽在不必替它碓甞。只要邀照上

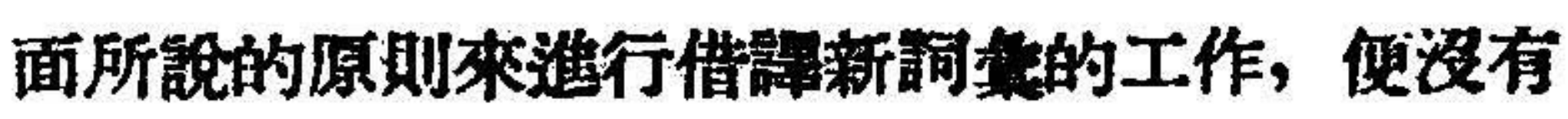

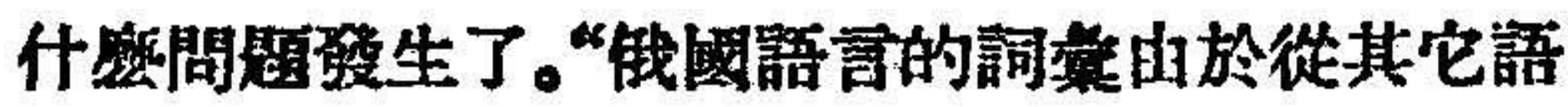
言中取得了影多詞而克筧起來了, 但是道前浔有 使俄國語言㓩弱, 相反地, 使它豐富和加强起來 了。至於俄國語言的民埃特質，並沒有受到絲毫的 損害, 因篇它保存了自己的文法構造和基本詞短

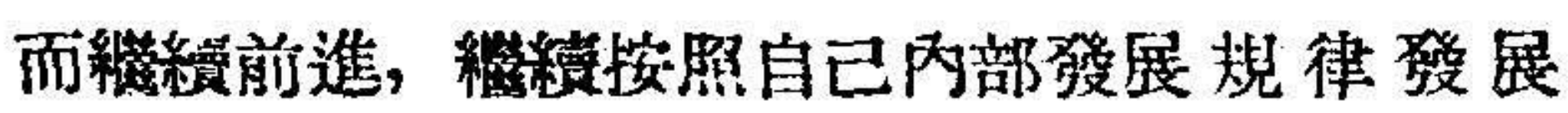
著。”斯大林同志已經很明確地對我們說出這一點 了。

斯大林同志又指示我們：蔀害是有粯風關係 的。“馬酮目空一切地指斥研究語言類别(系族)的

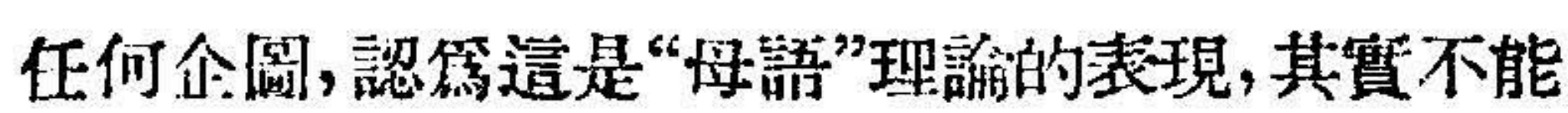

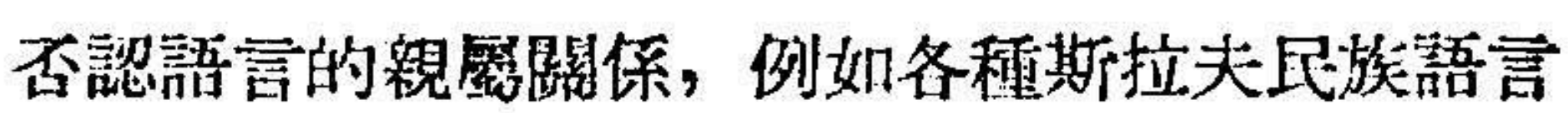

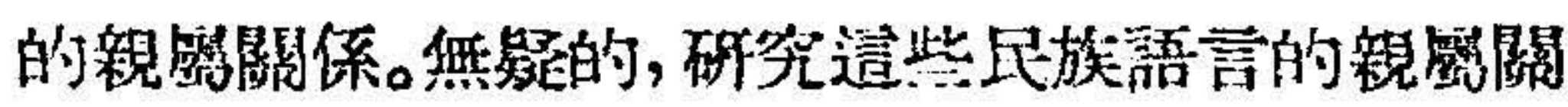

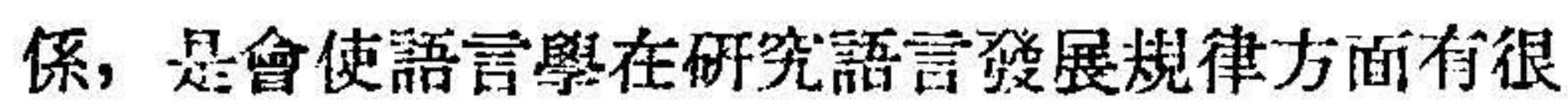
大爷處的。”少數民族語言工作者應該有計㓯地有 系統地將全國少數印族語言研究清楚, 理出各種

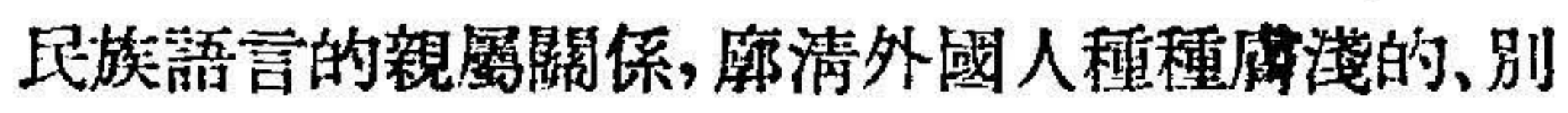

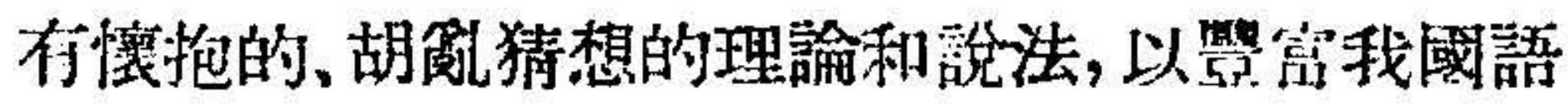
言學的內容。這種研究工作對我們的賽漈任弱付

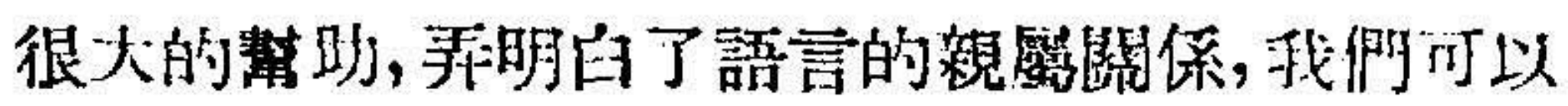
把很新的幾支語言合製成一種文字。他们踖言血 綵很近, 玨㝘相同相似之處必多, 訂成一種文字, 有種種好坺。事筫上有很多少數民族他們自動的

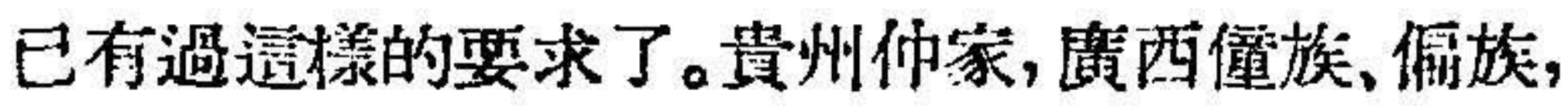
雲南交山沙族, 他們有些人會經主張在相近的語

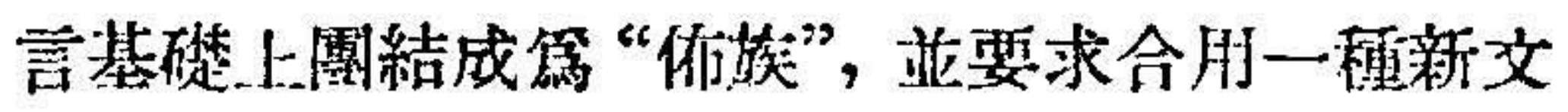

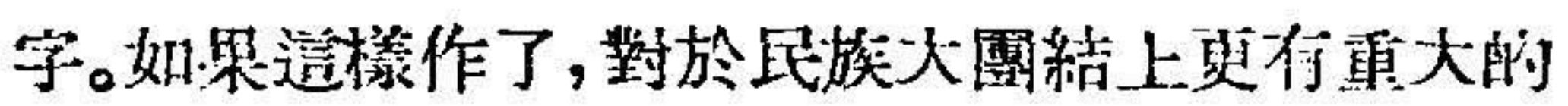

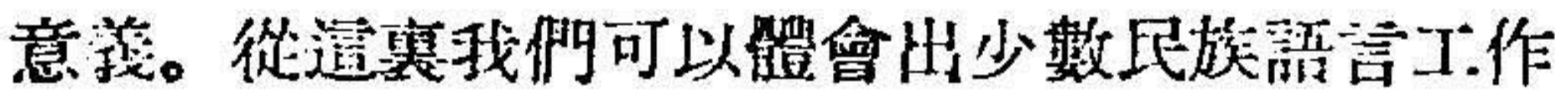

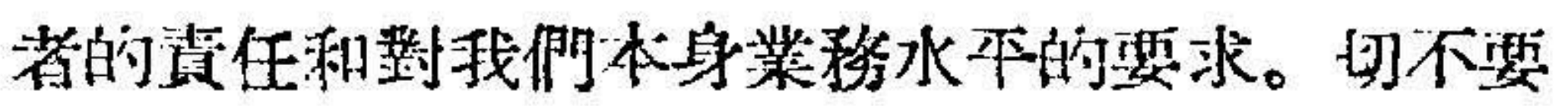
以䈍我們現在是搞“提高交化”的“普通”工作, 用 不着作精密的深入的科學的鑽研。沒有科學的語 言學的研究, 對提高少數民族交化水平的工作是 不會做得好的。通過學術性的研究, 迩到政治上的 日的,二者緊然結合, 才是我們工作的正碓方向。 